\title{
THE EFFECT OF SALINITY AND NITROGEN DEFICIENCY ON THE CHANGES IN SELECTED PHYSIOLOGICAL PARAMETERS OF COMMON BEAN (PHASEOLEUS VULGARIS L.) GROWN IN HYDROPONIC CULTURES
}

\author{
Jacek Wróbel' ${ }^{1}$ Alicja Auriga' ${ }^{1}$, Marcin Mielczarek ${ }^{1}$ \\ 1 Department of Plant Physiology and Biochemistry, Faculty of Environmental Management and Agriculture, \\ West Pomeranian University of Technology in Szczecin, 17 Słowackiego St., 71-434 Szczecin, Poland, e-mail: \\ jacek.wrobel@zut.edu.pl
}

Received: 2016.05 .25 Accepted: 2016.08.08 Published: 2016.09.20

\begin{abstract}
This study aimed at evaluating the physiological activity of common bean grown under the conditions of stress being induced by salinity and nitrogen deficiency and its lack in substrate. Three series of two-factorial hydroponic experiment with the common bean (Phaseolus vulgaris L.) cultivar Basta were carried out from May to July in 2013-2014. The first experimental factor was three levels of nitrogen content in a Hoagland hydroponic medium (level 1 - a complete medium, level 2 - without $50 \%$ $\mathrm{N}$, level 3 - without $100 \% \mathrm{~N}$ ). The second experimental factor was three levels of medium salinity (level $1-$ no $\mathrm{NaCl}$ addition, level $2-30 \mathrm{mM} \mathrm{NaCl}$ addition, level $3-50$ $\mathrm{mM} \mathrm{NaCl}$ addition). Nitrogen deficiency in a Hoagland hydroponic medium, together with increased salinity level, significantly affected the changes in the physiological parameters of the common bean cultivar Basta being tested, i.e. assimilation pigment concentration (chlorophyll-a, chlorophyll-b and chlorophyll- $\mathrm{a}+\mathrm{b}$ and carotenoids), assimilation and transpiration intensities, and RWC (relative water content). The 50\% nitrogen deficiency in medium induced a significant increase in the concentration of all assimilation pigments in common bean leaves and was by far the highest among the experimental variants being tested. A significant decrease in the content of assimilation pigments was observed in the hydroponic mediums without nitrogen and salined with 30 and $50 \mathrm{mM}$ sodium chloride. The interaction of these two experimental factors being analysed, i.e. nitrogen deficiency and its lack in a Hoagland hydroponic medium and its salinity, significantly decreased the intensity of assimilation in bean leaves, while a significant increase in transpiration was observed in the variant without nitrogen and with $50 \mathrm{mM} \mathrm{NaCl}$. The experimental variants being tested had a significant effect on the changes in leaf water balance of the common bean cultivar being tested. Salinity, in interaction with nitrogen deficiency in medium, decreased relative water content (RWC) in leaves, irrespective of their level.
\end{abstract}

Keywords: salinity, bean, hydroponics, nitrogen deficiency, assimilation pigments, gas exchange

\section{INTRODUCTION}

In Poland, the common bean (Phaseolus vulgaris L.) is an important cultivated plant, being valuable for nutritional reasons. Its seeds contain high-quality protein (on average approximately $25 \%$ ); they are also rich in phosphorus, potassium and iron [Jasiński i Kotecki 1999; Szafirowska and Kaniszewski 2014]. It has high thermal and light requirements and moderate water requirements. Of all legumes, it is the most resistant to drought. It also has a well-developed root system, with which the bacteria Rhizobium phaseoli that fix atmospheric nitrogen, being also used by the plant, coexist in a symbiotic relationship. As a result, its nutritional requirements with re- 
spect to nitrogen are much smaller. Therefore, it is not advisable to fertilise the bean with a large amount of mineral nitrogen. On the other hand, the bean has high nutritional requirements with respect to phosphorus and potassium. Nitrogen belongs to the so called macro-nutrients that determine the normal growth and development of plants. It is one of the basic structural elements of plants, being part of protein, but also is crucial in the production of crop yield of appropriate biological value. Its primary source for plants is nitrates $(V)$. Under the influence of plant nutrition with nitrogen and good supply of other nutrients for them, the highest crop yield increases are being obtained. However, the inefficient use of these chemical elements may adversely affect the quality of the obtained crop yield [Mazur 1991].

One major problem in the cultivation of common bean can be its high sensitivity to soil salinity [Starck 1980; Starck et al. 1995; Żuradzka 2000]. It is estimated that approximately $40 \%$ of the Earth's surface is affected by this negative phenomenon [Sacała 2008]. Salinity is caused by excessive accumulation of readily soluble inorganic salts in the soil solution. In the case of excessive salinity, the soil solution contains too much - in relation to plant needs - cations, such as $\mathrm{Mg}^{2+}, \mathrm{Ca}^{2+}, \mathrm{Na}^{+}, \mathrm{K}^{+}$, and anions, as $\mathrm{SO}_{3}{ }^{2-}, \mathrm{NO}_{3}$ ${ }^{-}, \mathrm{Cl}^{-}$[Telesiński 2012]. These salts may be the result of chemical decomposition of the minerals included in rocks and get into the soil with rainwater. However, the most often cause of excessive salt accumulation in soils is the use of high doses of fertilisers and other chemical compounds, especially where intensive cultivation is being carried out, which induces their secondary salinisation. Also inappropriate methods of soil irrigation using the water with high $\mathrm{NaCl}$ content (substitution of freshwater by sea-water) are another cause of salinity [Levitt 1972; Hillel 2012].

Most species of cultivated plants are sensitive to even relatively low salinity because excess salt in the root zone makes difficult for plants to remove water from the surrounding soil, thereby lowering the amount of water being available for plants [Zhu 2001; Boehm 2012]. A too high salinity disturbs homeostasis, water potential and ion distribution. A disturbed homeostasis occurs in both cells and the whole plant. Drastic changes in the homeostasis of ions and water may lead to molecular damage, growth inhibition, and even to plant death [Zhu 2011]. To minimise the negative effect of excess salt, plants synthesise and ac- cumulate the so called cytoplasmic osmoticums, among which amino acids and their derivatives play an important role. The accumulation of soluble nitrogen compounds in the plant cells in response to various unfavourable environmental factors is a common phenomenon that allows plants to adapt to stress conditions [Mansour 2000; Sacała 2008]. Nitrogen metabolism thus plays a major role not only in plant growth and their productivity but also in the processes that increase the tolerance of plants to environmental stresses [Sacała 2008]. During a long-term exposure to salinity, plants suffer from ionic stress which may lead to premature ageing of their leaves and thus reduce the area of photosynthesis, being essential for plant growth [Sultana et al. 1999; Muscolo et al. 2003]. One of the main indicators of leaf ageing is a decrease in the chlorophyll level [Prochazkova et al. 2001; Kaya 2003].

Soil salinity has a negative effect on the plant health, inhibits the growth processes, reduces the physiological activity, and leads to the physiological drought deteriorating water balance. For many years, the studies on new genotypes of the common bean have been carried out, in particular aiming at its greater resistance to stress factors, such as drought, low and high temperature, flooding, nutrient deficiencies and salinity.

The aim of this study was to evaluate the selected physiological parameters of common bean cultivar Basta grown under the conditions of stress being induced by salinity and nitrogen deficiency and its lack in substrate.

\section{MATERIAL AND METHODS}

In 2013-2014, from May to July, three series of a hydroponic experiment with the common bean (Phaseolus vulgaris L.) cultivar Basta were conducted. The seeds were first sown into a tray being filled with quartz sand. Then, after 7 days, the common bean seedlings were placed, after a thorough cleaning of their root systems, in aerated hydroponic systems, $150 \mathrm{ml}$ capacity each, being filled with a hydroponic medium according to Hoagland in different variants. The first experimental factor was the type of hydroponic medium, i.e. 3 levels of nitrogen in a Hoagland hydroponic medium: a complete medium, a medium without $50 \%$ nitrogen, and a medium without $00 \%$ nitrogen (Table 1), whereas the second factor was 3 levels of salinity in respective hydroponic medi- 
Table 1. Composition of hydroponic medium (amount of $1 \mathrm{M}$ salt solution in $\mathrm{cm}^{3}$ per $1 \mathrm{dm}^{3} \mathrm{H}_{2} \mathrm{O}$ ) according to Hoagland

\begin{tabular}{|c|c|c|c|}
\hline \multirow{2}{*}{$1 \mathrm{M}$ stock solution } & \multicolumn{3}{|c|}{ Type of hydroponic medium } \\
\hline & Complete & $-50 \% N$ & $-100 \% \mathrm{~N}$ \\
\hline $\mathrm{Ca}\left(\mathrm{NO}_{3}\right)_{2} \cdot 4 \mathrm{H}_{2} \mathrm{O}$ & 4 & 2 & \\
\hline $\mathrm{KNO}_{3}$ & 6 & 3 & \\
\hline $\mathrm{MgSO}_{4} \cdot 7 \mathrm{H}_{2} \mathrm{O}$ & 2 & 2 & 2 \\
\hline $\mathrm{NH}_{4} \mathrm{H}_{2} \mathrm{PO}_{4}$ & 2 & 1 & \\
\hline $\mathrm{CaCl}_{2}$ (anhydrous) & & 2 & 4 \\
\hline $\mathrm{KCl}$ & & 1 & 2 \\
\hline $\mathrm{NaH}_{2} \mathrm{PO}_{4} \cdot \mathrm{H}_{2} \mathrm{O}$ & & 1 & 2 \\
\hline $1 \% \mathrm{FeCl}_{3}$ & 1 & 1 & 1 \\
\hline $\begin{array}{l}\text { Solution }{ }^{1} \text { containing } \mathrm{B} \text {, } \\
\mathrm{Mn}, \mathrm{Zn}, \mathrm{Cu}, \mathrm{Mo}, \mathrm{Cl}\end{array}$ & 1 & 1 & 1 \\
\hline
\end{tabular}

${ }^{1}$ Per $1 \mathrm{dm} 3$ of distilled water: H3BO3 $-1.55 \mathrm{~g}$; $\mathrm{MnSO} 4 \cdot 4 \mathrm{H} 2 \mathrm{O}-1.10 \mathrm{~g} ; \mathrm{ZnSO} 4 \cdot 7 \mathrm{H} 2 \mathrm{O}-0.58 \mathrm{~g}$; $\mathrm{CuSO} 4 \cdot 5 \mathrm{H} 2 \mathrm{O}-0.12 \mathrm{~g}$;

(NH4)6Mo7O24.4H2O - $0.02 \mathrm{~g} ; \mathrm{NaCl}-3.12 \mathrm{~g}$

um types: no $\mathrm{NaCl}$ addition, $\mathrm{NaCl}$ addition in the amount of $30 \mathrm{mM} \cdot \mathrm{kg}^{-1}$, and $\mathrm{NaCl}$ addition in the amount of $50 \mathrm{mM} \cdot \mathrm{kg}^{-1}$. The control was a nonsaline complete Hoagland hydroponic medium.

Measurements of selected physiological parameters were made in four replications, after 14 days from the time the seedlings had been placed in different hydroponic medium variants. The intensity of $\mathrm{CO}_{2}$ assimilation (A) and water vapour transpiration (E) by common bean leaves was measured. The measurements were made using a PP Systems TPS-2 gas analysis system equipped with a leaf chamber (leaf cuvette) at the light intensity of $2053 \mu \mathrm{mol} \cdot \mathrm{m}^{-2} \cdot \mathrm{s}^{-1}$. The analyses were performed in an open configuration, in which the air was continuously passed through the leaf cuvette. Furthermore, the same leaves were used to determine the content of assimilation pigments, i.e. chlorophyll-a, chlorophyll-b, and total chlorophyll $(\mathrm{a}+\mathrm{b})$, by the Arnon's method [1956] as modified by Lichtemhaler and Welburn [1983], and carotenoids, according to the method by Hager and Mayer-Berthenrath [1966]. The extraction of pigments was performed in the samples of fresh green mass of the common bean leaves being homogenised with $10 \mathrm{ml}$ of $80 \%$ acetone. The optical density of supernatants was determine on a Marcel Mini spectrophotometer at wavelengths of 440,645 , and $663 \mathrm{~nm}$.

The water balance in common bean leaves was also measured by calculating the following indicators: RWC - relative water content, and WSD - water saturation deficit [Yamasaki and Dillenburg 1999]. For this purpose, fresh plant material was weighed on an analytical balance with $0.001 \mathrm{~g}$ readability. After weighing, the leaves were placed for 24 hours in the glass vessels being filled with distilled water. Next, the leaves were removed from the water, blotted and weighed again in order to determine the weight of leaves after full water saturation. The next step was to dry the plant material in an oven to a constant weight (at $80^{\circ} \mathrm{C}$ for 24 hours), then the dry weight was measured. The resulting data were used to calculate water balance indicators according to the following formulas: RWC $=[($ fresh weight - dry weight $) /$ (turgid weight - dry weight $)] \times 100 ; \mathrm{WSD}=[($ turgid weight dry weight $)$ - (fresh weight - dry weight $)$ / [(fresh weight - dry weight) $] \times 100$.

The results being presented in all figures are the averaged results from respective study years.

In order to determine the significance of interactions, a statistical analysis was performed using the Duncan's test, at the significance level $\alpha=0.05$. Homogenous groups were determined. The results were processed using Statistica 10 software package.

\section{RESULTS AND DISCUSSION}

Plants that grow under natural conditions are constantly exposed to stress factors. They can occur with varying intensity or exist in various variants simultaneously [Larcher et al. 1990]. Physiological and biochemical bioindication studies aim at finding sensitive and specific metabolic indicators, the changes of which will be useful to evaluate the differences in plant tolerance to abiotic stress factors. To evaluate the sensitivity of plants to stress, the measurement of physiological parameters, among others the content of assimilation pigments that determine the photosynthetic activity of plants and the same their productivity [Yanbao et al. 2006; Starck 2010], is adequate.

The results obtained in this study relating to the average content of assimilation pigments in the leaves of the common bean cultivar Basta being exposed to the stress induced by nitrogen deficiency and its lack in hydroponic medium and various salinity levels are presented in Figures 1-4. Hydroponic medium salinity, both 30 and 50 $\mathrm{mM} \mathrm{NaCl}$, did not have any significant effect on the changes in chlorophyll and carotenoid contents when compared to the control plants. 


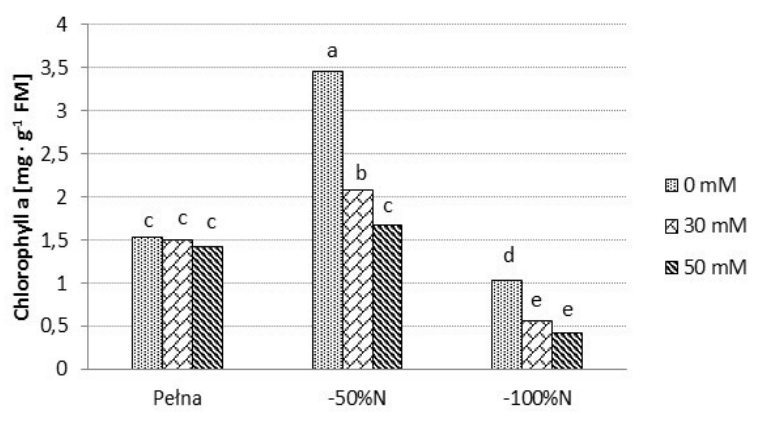

Figure 1. Chlorophyll-a content $\left[\mathrm{mg} \cdot \mathrm{g}^{-1}\right.$ f.w.] in common bean leaves according to nitrogen content in hydroponic medium and its salinity level

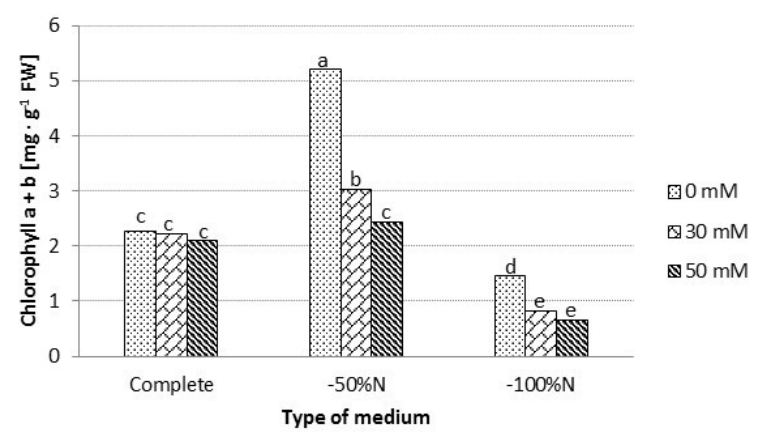

Figure 3. Chlorophyll $\mathrm{a}+\mathrm{b}$ content $\left[\mathrm{mg} \cdot \mathrm{g}^{-1}\right.$ f.w. $]$ in common bean leaves according to nitrogen content in hydroponic medium and its salinity level

Most studies that refer to the response of plants to substrate salinity have reported a decrease in the content of total chlorophyll and carotenoids in plant leaves as affected by the salt stress [Tuna et al. 2008; Parida and Das 2005; Herman et al. 20110; Silva et al. 2010]. Herman et al. [2010], who conducted a pot experiment determining the effect of different soil salinity $(10,20,30 \mathrm{mM}$ $\mathrm{NaCl}$ ) on the content of total chlorophyll and carotenoids in the leaves of string bean (Phaseolus vulgaris L., cv. Złota Saxa), have shown that the content of assimilation pigments in the bean leaves depended to a large extent on soil salinity level. The soil salinity decreased chlorophyll and carotenoid contents in leaves, the decrease being however greater the higher was the level of salinity. The content of chlorophyll and carotenoids in the dry weight of leaves of the bean growing in the soil with a lower salinity level was similar to their level in the control plants, whereas higher salinity levels induced a significant decrease in the content of these assimilation pigments, by more than $20 \%$.

The cultivar Basta being tested in this study proved to be more tolerant to salinity than the cultivar Złota Saxa examined in the study by

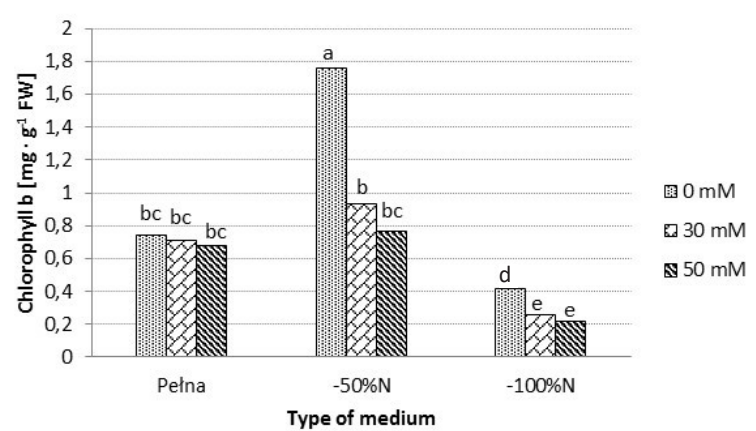

Figure 2. Chlorophyll-b content $\left[\mathrm{mg} \cdot \mathrm{g}^{-1}\right.$ f.w.] in common bean leaves according to nitrogen content in hydroponic medium and its salinity level

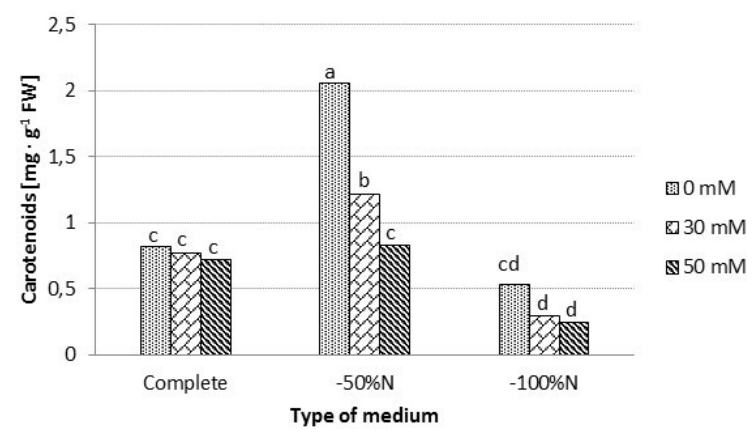

Figure 4. Carotenoids content $\left[\mathrm{mg} \cdot \mathrm{g}^{-1} \mathrm{f}\right.$.w. $]$ in common bean leaves according to nitrogen content in hydroponic medium and its salinity level

Herman et al. [2010]. According to some authors [García-Sánchez et al. 2002; Noreen and Ashraf 2009], changes in the content of photosynthetic pigments also depends on the tolerance of plants to soil salinity, i.e. on their genotype.

In the present study under discussion, significant changes in the content of assimilation pigments were observed in the interaction between nitrogen deficiency and its lack in hydroponic medium and the level of its salinity. The lack of nitrogen in hydroponic medium induced a significant decrease in the content of chlorophyll-a, chlorophyll-b and total chlorophyl and carotenoids in common bean leaves (Figures 1-4), irrespective of the level of its salinity. However, the salinity level induced by salt addition in the amount of 30 i $50 \mathrm{mM} \mathrm{NaCl}$ intensified the decrease in the content of these pigments, by approximately $120 \%$ as compared to the control (complete Hoagland hydroponic medium). In the study by Grzyś [2012], the nitrogen deficiency in substrate, being further deepened by the osmotic stress associated with salinity, was the cause of a significant decrease in the concentration of assimilation pigments, especially chlorophyll, in maize leaves. Martinez and Creda [1989] are of the opinion that the $\mathrm{Na}+$ 


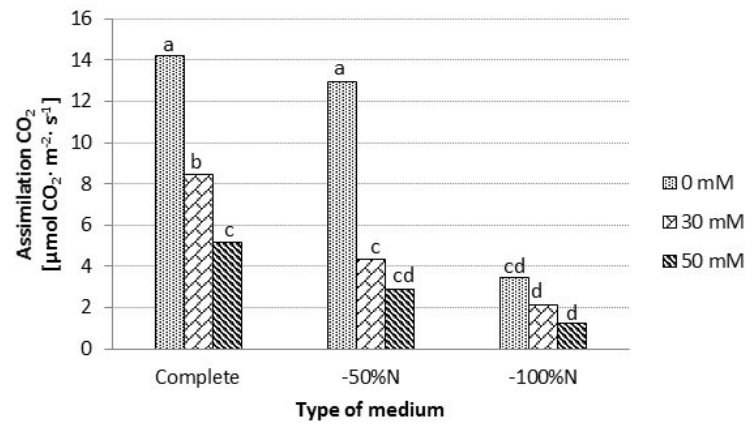

Figure 5. Intensity of $\mathrm{CO}_{2}$ assimilation and transpiration $\left[\mu \mathrm{mol} \mathrm{CO} \cdot \mathrm{m}^{-2} \cdot \mathrm{s}^{-1}\right]$ in common bean leaves according to nitrogen content in hydroponic medium and its salinity level

and $\mathrm{Cl}$ - ions being present in leaves may limit the transport of nitrate ions from vacuole into cytoplasm. As affected by salinity, large amounts of ions are accumulated in older leaves and this is just them where the first effects of salt stress can be observed. Leaves typically change colour as a result of chlorophyll breakdown; leaf blade margins turn brown and dry out, whereas in the central part the leaf remains green.

In the experiment carried out, a 50\% nitrogen deficiency in a non-saline hydroponic medium induced a significant decrease (more than 2-fold) in the content of all measured assimilation pigments as compared to the control. Nitrogen is one of the more important factors determining the content of photosynthetic pigments that affect plant development. In the case of leguminous plants, requirements for this chemical element are not large due to their symbiosis with root nodule bacteria of the genus Rhizobium which are capable of covering the demand for nitrogen almost completely by binding it from the atmosphere [Mazur 1991].

A small but significant effect on the increase in the content of total chlorophyll and carotenoids, as compared to the control, had the salinity level of $30 \mathrm{mM} \mathrm{NaCl}$ in the hydroponic medium lacking $50 \% \mathrm{~N}$. On the other hand, a higher salinity level of the same hydroponic medium (50 $\mathrm{mM} \mathrm{NaCl}$ ) did not have any significant effect on changes in the concentration of these pigments.

The present experiment demonstrated a significant effect of the interaction of hydroponic medium salinity and nitrogen deficiency and its lack on the intensity of assimilation and transpiration in common bean leaves (Fig. 5-6). The highest activity of these processes was characteristic of the plants from the control variants. The salinity level of complete hydroponic medium induced

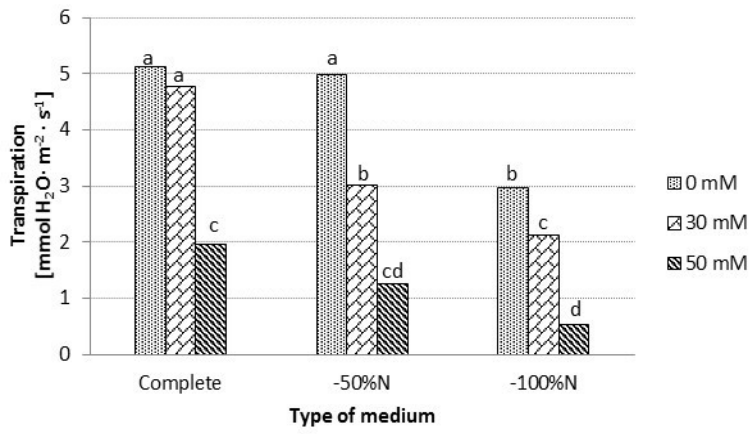

Figure 6. Intensity of transpiration $\left[\mathrm{mmol} \mathrm{H}_{2} \mathrm{O} \cdot \mathrm{m}^{-2} \cdot \mathrm{s}^{-1}\right.$ ] in common bean leaves according to nitrogen content in hydroponic medium and its salinity level

by the two $\mathrm{NaCl}$ doses significantly decreased the intensity of common bean assimilation, the decrease being however greater the higher was the level of salinity. On the other hand, in the case of transpiration, only a $50 \mathrm{mM}$ dose significantly decreased the intensity of this process. These results confirm the study being carried out by Matuszak et al. [2004] and Grendysz and Wróbel [2015] according to which the intensity of $\mathrm{CO}_{2}$ assimilation and transpiration decreased with the increase of hydroponic medium salinity level. It is related to a decrease in leaf turgid, closing of stomata, and hence reduced gas exchange.

Continuing with the discussion of the results of this study, it was demonstrated that a $50 \%$ nitrogen deficiency in a non-saline hydroponic medium did not have any significant effect in the gas exchange of common bean leaves. The intensity of the two processes was the level being similar to that in the control plants. On the other hand, the salt addition to a hydroponic medium without $50 \% \mathrm{~N}$ induced a significant decrease in both assimilation and transpiration. The intensity of gas exchange in common bean leaves significantly decreased with the increase of salinity level and nitrogen deficiency in hydroponic medium. In a combination of the lack of nitrogen and the highest salinity level $(50 \mathrm{mM} \mathrm{NaCl})$, it was approximately $10-11$-fold lower than under control conditions.

Starck [1980, 1993. 2010] has reported that the harmful effect of $\mathrm{NaCl}$ contributes mainly to disturbances in water balance, which results in extreme cases in plant wilting due to poor water absorption and reduced physiological activity.

The present study demonstrated a significant effect of the level of hydroponic medium salinity and nitrogen deficiency on the decrease of 


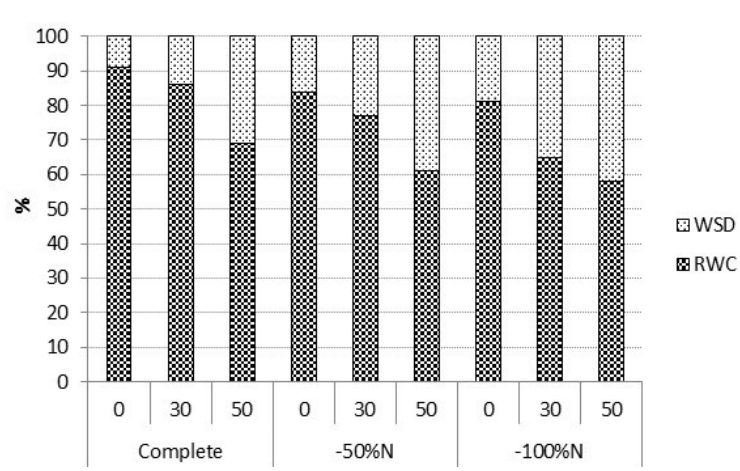

Figure 7. Relative water content [RWC] and water saturation deficit [WSD] in common bean leaves according to nitrogen content in hydroponic medium and its salinity level

relative water content (RWC) and the increase of water saturation deficit (WSD) in common bean leaves (Fig. 7), with the increase of salinity having a greater effect than nitrogen deficiency in hydroponic medium. The highest RWC was characteristic of the plants being grown in a complete hydroponic medium (control medium) - more than $90 \%$. On the other hand, its salinity level induced by sodium chloride addition in the amount of $50 \mathrm{mM}$, as well as its deprivation of nitrogen, induced the highest decrease in RWC in common bean leaves - to approximately $58 \%$. a similar decrease in relative water content (RWC) in the leaves of various plants, to approximately $61-62 \%$, as affected by the salinity level has been observed by Bandurska [1991] and Wróbel and Mikiciuk [20110]. According to Kacperska [1996] and Matuszak i Brzóstowicz [2006] negative water balance is a commonly recorded response of the whole plant to various stresses, in particular being induced by salinity, and leads to a reduction of water uptake by the plant root system. Excess salt in soil reduces the hydration of cells, inducing a decrease in turgid. The character of salt, plant species, and even its individual properties, as well as other factors, determine the concentration at which particular plants die.

\section{CONCLUSION}

1. In the common bean cultivar Basta, the symptoms of stress being mainly induced by the interaction of Hoagland hydroponic medium salinity and the lack of nitrogen. This cultivar turned out to be quite tolerant to nitrogen deficiency and lower salinity.
2. The content of assimilation pigments, gas exchange and leaf hydration indicators (RWC and WSD) depended on the salinity and nitrogen deficiency levels in a Hoagland hydroponic medium.

3. Hydroponic medium salinity and its interaction with a $50 \%$ nitrogen deficiency did not have any effect on changes in the content of assimilation pigments. Only the lack of nitrogen in hydroponic medium significantly reduced chlorophyll and carotenoid contents. On the other hand, nitrogen deficiency in hydroponic medium induced a significant increase (approximately 2 -fold) in the content of these pigments.

4. Salinity decreased the intensity of assimilation and transpiration and relative water content (RWC) in the leaves of common bean cultivar Basta. Additionally, nitrogen deficiency, and especially its lack in hydroponic medium, significantly increased this decrease.

\section{REFERENCES}

1. Arnon D.J., Allen M.B., Whatley F.1956. Photosynthesis by isolated chloroplast. IV General concept and comparison of three photochemical reactions. Biochim. Biophys. Acta, 20, 449-461.

2. Boehm B. 2012. The Impact of an Alternative Deicing Product on Urban Storm Basin Salinit. Environmental Science: Water \& Life, 1-31.

3. García-Sánchez F., Jifon J.L., Carvajal M., Syvertsen J.P. 2002. Gas exchange, chlorophyll and nutrien contents in relation to $\mathrm{Na}+$ and $\mathrm{Cl}-$ accumulation in 'Sunburst' mandarin grafted on different rootstocks, Plant Sci., 162, 705-712.

4. Grendysz J., Wróbel J. 2015. Wpływ zasolenia i niedoboru potasu na zmiany cech fizjologicznych fasoli zwyczajnej (Phaseolus vulgaris L.) uprawianej w hydroponikach. Badania i Rozwój Młodych Naukowców w Polsce. Monografie Nauki przyrodnicze Tom I Część I Poznań. 2, 27-33.

5. Grzyś E. 2012. Wpływ wybranych substancji biologicznie czynnych na kukurydzę uprawianą w warunkach stresu. Monografie CXLV. Uniwersytet Przyrodniczy we Wrocławiu, 7-101.

6. Hager A., Mayer-Berthenrath T.1966. Die Isolierung und quanttative Bestimung der Carotenoide und Chlorophyll von Blatern, Algen und isolierten Chloroplasten mit Hilfe Dunnschicht-chromatographischer Methoden. Planta. Berlin, 69, 198-217.

7. Herman B., Biczak R., Rychter P. 2010. Reakcja fasoli szparagowej na zasolenie podłoża. Chemistry, Environment, Biotechnology 14, 111-120. 
8. Hillel D. 2012. Zasolenie i zawartość sodu, Gleba w środowisku. PWN Warszawa 157.

9. Jasiński Z., Kotecki A. 1999. Szczegółowa uprawa roślin. Wyd. AR Wrocław.

10. Kacperska A. 1996. Czy można mówić o wspólnym podłożu odpowiedzi roślin na działanie stresowych czynników środowiska. Konf. „Ekofizjologiczne aspekty reakcji roślin na działanie abiotycznych czynników stresowych". Kraków, 49-59.

11. Kaya C., Kirnak H., Higgs D., Saltali K. 2002. Supplementary calcium enhances plant growth and fruit yield in strawberry cultivars grown at high $(\mathrm{NaCl})$ salinity, Sci. Hort., 93, 2002, 65-74.

12. Larcher W., Wagner J, Thammathawron A. 1990. Effect of superimposed temperature stress on in vitro chlorophyll fluorescence of Vigina unguiculata under saline stress. Plant Physiol. 136, 92-102.

13. Lichtenthaler H. K., Wellburn A. R. 1983. Determinations of total carotenoids and chlorophyll a and bof leaf extracts in different solvents. Biochem. Soc. Trans., 11, 591-592.

14. Levit J. 1972. Responses of plants to environmental stresses Academic Press. New York.

15. Mansour M.M.F., 2000. Nitrogen containing compounds and adaptation of plants to salinity stress. Biol. Plant., 43, 491-500.

16. Martinez V., Creda A. 1989. Nitrate reductase activity in tomato and cucumber leaves as influence by $\mathrm{NaCl}$ and source. J. Plant Nutr., 12, 1335-1350.

17. Matuszak R, Baranowski P, Walczak R, Brzóstowicz A. 2004. Ocena wpływu zasolenia na wzrost, fotosyntezę, potencjał wody i temperaturę liści siewek pszenicy odmiany Almari. Acta Agrophysica, 99-101.

18. Matuszak R., Brzóstowicz A. 2006. Ocena wpływu chlorku sodu na wzrost siewek dwóch odmian jęczmienia, Acta Agroph., 7(4), 977-982.

19. Mazur T. 1991. Azot w glebach uprawnych : praca zbiorowa. PWN. Warszawa, 9-121.

20. Muscolo A., Panuccio M.R., Sidari M. 2003. Effects of salinity on growth, carbohydrate metabolism and nutritive properties of kikuyu grass (Pennisetum clandestinum Hochst), Plant Sci., 164, $1103-1110$

21. Noreen Z., Ashraf M. 2009. Assessment of variation in antioxidative defence system in salt-treated pea (Pisum sativum) cultivars and its putative use as salinity tolerance markers, J. Plant Physiol., 166, 1764-1774.

22. Parida A.K., Das A.B. 2005. Salt tolerance and salinity effects on plants: a review, Ecotox. Environ. Safety, 60, 324-349.

23. Prochazkova D., Sairam R.K., Srivastava G.C., Singh D.V. 2001. Oxidative stress and antioxidant activity as the basis of senescence in maize leaves, Plant Sci., 161, 765-771.

24. Sacała E. 2008. Wpływ umiarkowanego stresu solnego na wzrost oraz asymilację azotanów w siewkach ogórka. Zeszyty naukowe Uniwersytetu Przyrodniczego we Wrocławiu Nr 568; 37-48

25. Silva E.N., Ribeiro R.V., Ferreira-Silva S.L., Viégas R.A., Silveira J.A.G. 2010. Comparative effects of salinity and water stress on photosynthesis, water relations and growth of Jatropha curcas plants, J. Arid Environ., 74, 1130-1137.

26. Starck Z. 2010. Wpływ warunków stresowych na koordynację wytwarzania i dystrybucji fotoasymilatów. Post. Nauk Rol., 1, 9-26.

27. Starck Z. 1980. Fizjologiczna reakcja roślin na zasolenie ze szczególnym uwzględnieniem roli regulatorów wzrostu. Wiadomości Botaniczne, 178-184.

28. Starck Z., Chołuj D., Niemyska B. 1995. Fizjologiczne reakcje roślin na niekorzystne czynniki środowiska. Wyd. SGGW, Warszawa.

29. Sultana N., Ikeda T., Itoh R. 1999. Effect of $\mathrm{NaCl}$ salinity on photosynthesis and dry matter accumulation in developing rice grains, Environ. Exp. Bot., 42, 211-220.

30. Szafirowska A., Kaniszewski S. 2014. Instrukcja uprawy fasoli zwykłej na nasiona w warunkach ekologicznych. Instytut Ogrodnictwa Skierniewice, 1-10.

31. Szwonek E. 2004. Potas gwarantem plonowania i jakości roślin warzywnych. Instytut Sadownictwa i Kwiaciarstwa w Skierniewicach, 1-8.

32. Telesiński A. 2012. Wpływ zasolenia na wybrane biochemiczne wskaźniki żyzności gleby. Wodaśrodowisko - obszary wiejskie. Instytut Technologiczno-Przyrodniczy w Falentach 12(37), 209-217.

33. Tuna A.L., Kaya C., Higgs D., Murillo-Amador B., Aydemir S., Girgin A.R. 2008. Siliconimproves salinity tolerance in wheat plants, Environ. Exp. Bot., $62,10-16$.

34. Wróbel J., Mikiciuk M. 2010. Water and ionic balance in the leaves of basket willow (Salix viminalis L.) cultivated in hydroponics with different salinity levels. Ecological Chemistry and Engineering A, 17(10), 1315-1321.

35. Yanbao L., Chunying Y., Chunyang L. 2006. Differences in some morphological, physiological, and biochemical responses to drought stress in two contrasting populations of Populus przewalski. Physiologia Plantarum 127(2), 182-191.

36. Yamasaki S., Dillenburg L.R. 1999. Measurements of leaf relative water content in Araucaria angustifolia. Rev. Bras. Fisiol. Vegetal. 11(2), 69-75.

37. Zhu JK. 2001. Plant salt tolerance. Trends Plant Sci. 6, 66-71.

38. Zhu JK. 2011. Salt and Drought Stress Signal Transduction in Plants, Annu. Rev. Plant Biol. 2002(53), 247-273.

39. Żuradzka I. 2000. Fasola zwykła (Phaseolus vulgaris L.), fasola wielokwiatowa (Phaseolus coccineus L.) W: Duczmal K.W., Tucholska H. (Eds) Nasiennictwo: T. 2. Rozmnażanie materiału siewnego. PWRiL. Poznań, 179-183. 